\title{
SELECTED PROBLEMS OF CORRUPTION AND ANTI-CORRUPTION POLICY IN PUBLIC ADMINISTRATION
}

\author{
Lucie KAMRÁDOVÁ, Marie SCISKALOVÁ* \\ Faculty of Public Policies in Opava, Silesian University in Opava, \\ Bezručovo nám. 885/14, 74601 Opava, Czech Republic
}

Received 28 February 2021; accepted 01 April 2021

\begin{abstract}
Purpose - the aim of the paper is to focus on the issue of corruption in public administration and to compare this phenomenon in relation to the extent that affects individual spheres of state functioning, especially in public administration.

Research methodology - the article will use mainly qualitative research methods to achieve the goal. The methodology of the work is based in the first part of the analysis of the theoretical basis, which uses a comparison within the European Union. The practical results of quantitative research through a questionnaire survey are presented in the final part of the paper.

Findings - results can be used for both academic and social purposes and further research in this area.

Research limitations - the article sees its limits in a broader comparison from an international perspective.

Practical implications - the results can serve as a comprehensive material for further research, or an example of socalled Good Practice, how public administration can manage the issue of corruption.

Originality/Value - the article in its essence deals with an original topic from the perspective of one country and performance of public administration in the field of corruption.
\end{abstract}

Keywords: corruption, law, official, government, public administration.

JEL Classification: L32, H83, K49.

Conference topic: Contemporary Issues in Economics Engineering.

\section{Introduction}

In today's society, sufficient attention is paid to the issue of corruption, both from a media and social point of view. In general, we can talk about a phenomenon that exists at the same time as humanity itself. However, the issue of corruption is not only at the economic, legal or social level, but it is much deeper. It is based on the moral credit of each individual. This credit can be influenced to some extent by the environment in which the individual grows, however, the problem occurs if the individual is confronted directly in their job. Here it depends on personal credit and the will to resist the benefit at the expense of others.

This article focuses primarily on the issue of definition of corruption and the position of individual organizations on this issue. In the next part of the article, attention is paid to the perception of corruption and corrupt practices at the level of officials of territorial self-governing units (hereinafter referred to as TSU). The aim of the paper is to focus on the issue of corruption in public administration and to compare this phenomenon in relation to the extent that affects individual spheres of state functioning, especially in public administration at the local level. The object of the empirical survey are officials of selected municipalities and regions. A special chapter is devoted to transparency of the public sector and open access to information, where it was determined whether and how officials use the National Open Data Catalog (NKOD), which is operated by the Ministry of the Interior on Public Administration Portal of the Czech Republic. The data are further supplemented by the view of officials on the issue of corruption and corrupt practices, which they encountered in the performance of their profession. In connection with the current findings that the Czech Republic fell on the ranking of Transparency International, which monitors corruption, fell by five places

\footnotetext{
*E-mail: lucie.kamradova@fvp.slu.cz
} 
in 2020 compared to the previous year, it ranked 49th. According to the authors, it is desirable to draw attention to the continuing negative evaluation of the Czech Republic, which on last year's TI index was six points worse than in the previous period (Czech Press Office, 2021).

In essence, the article uses a combination of quantitative and qualitative research, analysis, comparison, synthesis and, last but not least, a questionnaire survey, whose results are shown in Chapters 4 and 5. The article uses mainly literature focused on corruption in the Czech Republic, but also relies on documents created on the territory of the European Union. The authors are aware of the limits of this paper and present only a possible direction in which further research in this area can be taken. The literature mentioned in this article is based mainly on legal documents and strategies. Nevertheless, it still tries to use professional literature that is related to the issue. However, connection of this topic with legal regulations is, according to the authors, desirable and undeniable. Especially with regard to the seriousness of the topic not only in the selected country (the Czech Republic) but also in other countries, ie in the European Union.

\section{Corruption as a global issue}

In fact, since the 1990s, the concept of corruption has been appearing more and more frequently in professional and political debate. The negative effects of corruption on the legitimacy of political regimes, the national economy, the functioning of private businesses or even the environment are discussed. Its occurrence is studied and measured, scientists dealing with social sciences (especially economics and sociology, but also law and philosophy or ethics) try to propose such measures on the basis of their research, which would atleast reduce occurrence of corruption. The fact that corruption is so intensively talked about and written is relatively new. In the period preceding the 1990s, corruption was a taboo, even though the evidence for its existence was undeniable. Only in the mentioned period, which was caused, among other things, by the fall of the Eastern Bloc, the problem of corruption gets on the agenda of national governments and international organizations (Cohen, 2007). It is important to note that at this time, non-governmental organizations began to assert themselves internationally, which had to combat this phenomenon in as part of their job, such as Transparency International.

Lord Acton ${ }^{1}$ once made the famous statement that "power corrupts" and added that "absolute power corrupts absolutely". Today, although no one has absolute power in democratic regimes, the tendency of the powerful to govern even with the help of corruption is evident. Corruption is a borderless phenomenon, it occurs in all types of regimes and in all historical periods. (Ministry of the Interior Czech Republic, 2008) However, to some extent it also depends on the moral maturity of the society in which corruption occurs. The word "corruption" itself comes from Latin and is based on the word base "rumpere", ie to break, smash, break down. The Latin word "corruptus" refers to the consequence of such a break and causes the person concerned to be forced to change his attitudes, principles and opinions.

But how can the concept of corruption be understood when it is basically clear what it means but for many it is part of social life. For example, Transparency International defines corruption as an abuse of power to gain undeserved personal gain. It means the conduct of public sector officials (whether politicians or civil servants) in which they enrich themselves illegally through the abuse of powers conferred on them (Transparency International, 2000).

For example, Frič talks about corrupted behavior as a deviation from compliance with legal norms and standard behavior of the majority society. In essence, it can be said that corruption is a betrayal of obligations to the majority and its moral principles (Frič et al., 1999).

From the statement above, it is clear that the definition of corruption is based on and always defines the following. Corruption is:

- Guided by greedy goals, namely the desire for profit or other personal gain. However, the unjustified advantage which the bribed person receives does not necessarily have to be in the form of money.

- Corruption relationships do not have to appear only in the relationship of a private person to a "public official", but it can also occur in case of two private persons. A typical example are business dealings.

- There are not only two parties in a corruption relationship, but always three. The third, passive and more or less apparent, is always a damaged party.

- The consequence of corruption is that public institutions cease to serve the public interest and conversely, become a platform for monitoring private interests.

These can be summarized in the general definition, which is presented by Transparency International and with which the authors of the paper also agree. Corruption therefore means conduct by which person in a certain qualified position (elected representative, public servant, public sector employee, but also a person in a certain position in the private sector) abuses his position for personal enrichment or enrichment of third parties. This conduct can be of direct benefit to those who provoke corrupt practices, and damage always occurs to varying degrees to a identifiable group of individuals and legal entities (Transparency International, 2005a).

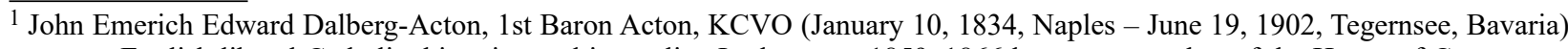
was an English liberal Catholic, historian and journalist. In the years 1859-1866 he was a member of the House of Commons.
} 
Of course, corruption is also related to this issue as a problem that appears in various parts of society. Various exhaustive definitions of corruption from several perspectives serve to define this problem. Organizations and authors look at the issue of corruption and its classification from different perspectives. The most basic division, which is intertwined in every sphere of social life, is the division into large and small corruption or small and political corruption (Sawyer, 2000). For needs of the paper, the authors chose the breakdown, which is shown in Table 1. When the basic breakdown is based on the so-called small administrative corruption and the second area is represented by the misuse of public resources. Both of these categories then include the sub-areas in which corruption specifically affects public administration.

Table 1. Typology of corruption in public administration (source: Own processing according to Karklins, 2002)

\begin{tabular}{|l|l|}
\hline \multicolumn{1}{|c|}{ Small administrative corruption } & \multicolumn{1}{c|}{ Misuse of public resources } \\
\hline Bribery of officials & Embezzlement of public resources \\
\hline $\begin{array}{l}\text { Intentionally confusing regulations, obscuring rules, } \\
\text { poor organization }\end{array}$ & Uneconomical use of public resources \\
\hline $\begin{array}{l}\text { Abuse of powers arising from the supervisory activities } \\
\text { of the public administration }\end{array}$ & Private benefits from privatization \\
\hline & Abuse of official authority in the award of public contracts \\
\hline & Nepotism, clientelism, or "sale" of jobs \\
\hline
\end{tabular}

In the event that there is an insufficient definition of public supervision and control mechanisms, there is a phenomenon where it is possible for individual officials to be bribed by private entities in order to secure some advantage from them. Bribery can then either be conducted by private entities or conversely can be required by the officials themselves. Related to this is the issue of abuse of power as a result of the creation of excessive and confusing regulation by the state (Králíček \& Molín, 2014). In the second area, concerning the misuse of public resources, as mentioned above, it can occur in several areas. In general, this type of corruption creates the conditions for corruption to be organized in its own right. In essence, a corrupt network of mutual services and counter-services is created within the organization of public administration itself, which then leads to inefficient management of public resources (OECD, 2004). This is proved by the cases from the so-called post-communist Eastern Europe, when privatization or its abuse as also added to these types. An interesting item, however, is the issue of so-called clientelism ${ }^{2}$ and nepotism ${ }^{3}$, which is, however very widespread. In essence, it is a matter of favoring a certain group of people by persons entrusted with the exercise of public power. We can rightly consider this phenomenon as one of the most serious forms of corruption.

\section{Legislation and international anti-corruption instruments and figures}

The most serious forms of corruption can be considered to be those that have interstate, even transnational overlap and effects. In today's world, there is an increasingly urgent need to tackle corruption, for example in the arms trade or the corruption of multinational corporations against entire governments of economically weaker countries. They often buy permits for activities that could not be legally allowed even in countries with lower demands on environmental, social or health standards (Econnect, 2004). concluding international agreements against corruption and its individual aspects, association in international organizations, adoption of programming documents (action plans), informal cooperation of countries within various programs or in the form of support for research and analysis. An interesting view of the issue of corruption appears in the publication Corruption and Government. Causes, Consequences, and Reform ${ }^{4}$, where the authors assume a corrupt environment that needs to be detected and minimized by subsequent system reform.

The most basic division of anti-corruption norms in the international field is into the so-called hard law and soft law. Hard law is international law in the narrower sense - it is directly binding. In the field of the fight against corruption, these are international treaties, which are in fact similar to the law in national law - the difference is that they bind only their signatories, while the law of everyone under its jurisdiction. Various recommendations, action plans, declarations, rules such as "uidelines" and alike are considered soft law. Their violation does not constitute direct international liability. Examples are the International Code of Conduct for Public Officials (UN Resolution

\footnotetext{
${ }^{2}$ Clientelism (from the Latin cliens - obedient) is a term denoting the preference of friends and related groups. It is based on the relationship between dependent clients and their patron (Ministry of the Interior of the Czech Republic, 2005).

${ }^{3}$ Nepotism is a way of applying, consolidating and expanding the influence of an important individual on social structures through the promotion of one's own relatives and favorites into lucrative and socially influential positions and roles (Ministry of the Interior of the Czech Republic, 2005).

${ }^{4}$ Rose-Ackerman, Susan. Corruption and government. Causes, consequences, and reform. Cambridge University Press.
} 
51/59 of 1996b) or the UN Declaration against Bribery in International Business Transactions (UN Resolution 51/191 of 1996a).

The United Nations has traditionally been active in the fight against corruption as a vital problem for the entire international community. Within its framework, there are two key anti-corruption agreements. The first is the UN Convention against Corruption, adopted in 2003. It was soon signed by an unprecedented number of states (already in April 2004 it was 106 countries), which illustrates the seriousness of the problem of corruption. The UN's second treaty is the Convention against Transnational Organized Crime, adopted in 2000 in Palermo (United Nations Convention against Transnational Organized Crime). A very important organization engaging its considerable capacity to fight corruption is the Council of Europe, a community of European countries wider and older than the European Union (founded in 1949; it currently has 46-member states). This organization focuses not on economics, but on human rights, democracy and the rule of law. Its contribution to the fight against corruption is two elaborate international treaties from the end of the 1990s, which solve the problem of both criminalization instruments (criminal law) and civil law instruments. The Civil Law Convention on Corruption was adopted in November 1999 (Civil Law Convention on Corruption, ETS No. 174 - Council of Europe, 1999). Other important documents adopted at the international level include: the Council of Europe Convention on Insider Trading (ETS No. 130 - Council of Europe, 1989), the Convention on Combating Bribery of Foreign Public Officials in International Business Transactions), Convention on the Fight against Corruption, relating to Officials of the European Communities or Officials of the Member States of the European Union of May 1997 (Inter-American Anti-Corruption the 1996 Inter-American Convention against Corruption and the Dakar Declaration on the Future Competitiveness of African Economies. While the first is typical hard law, on the other hand the Declaration is representative of soft law instruments.

\section{Occurrence of corruption in public administration and its indicators}

Executive power in democratic states is usually exercised through the president, government, and system of public administration. The activity of public administration is then generally divided into activity of lordship and the activity which consists in provision of certain public services and goods. In the first case, subject of activity of individual public administration bodies is the legally permitted regulation of the behavior of managed persons through authoritative interference with their legal relations (Chmelík \& Tomica, 2011). It is undeniable that the public administration also acts as a subject of private law relations, when it manages the property entrusted to it, or when it purchases services from private entities for its own needs. In all these areas, there is room for corrupt relations, which always go against the proper performance of public administration tasks.

\subsection{Occurrence of corruption within the authority of public administration and its indicators of corruption 5}

In the context of public administration, corruption can pursue objectives such as speeding up the issuance of a decision (in which case the injured parties are all those who are the addressees of the same type of decision the payer is interested in issuing) and issuing a decision in favor of the payer (in this case, person that is bribing is trying to get a decision that is contrary to the public interest).

The cause of corruption within the authority of public administration is mainly insufficient salary evaluation of employees of the relevant authorities. Another cause of corruption in this area are delays in proceedings in which a participant seeks the issuance of a decision in its favor (granting a consent, permit, concession, accreditation or certificate by the public administration) or another decision (eg entry in a certain register). Delays in these proceedings are often caused by insufficient technical, material or personnel equipment of competent office or shortcomings in the organization of work within this authority. Another cause of corruption in this area is inability to obtain remedies to change relevant decision, either through public administration (typically by appeal) or through the courts (administrative justice) ${ }^{6}$. Corruption is also given space by missing or insufficiently set internal standards for the performance of individual administrative activities and a missing or ineffective system for monitoring compliance. Finally, insufficient ethical standards for the functioning of relevant authority (missing or ineffective code of ethics) may be behind the corruption in this area (Transparency International, 2005b).

Indicators of corruption within the authority of public administration can then be considered:

- quick decisions in situations where the Office usually decides in longer time limits (and vice versa: delays in proceedings in situations where in other cases the Office decides in shorter time limits);

- "bullying" exercise of official powers;

\footnotetext{
$\overline{5}$ This group includes administrative and tax proceedings, supervision, as well as other activities of public administration, which the public administration authoritatively interferes with the rights and legally protected interests of entities not subordinate to each other.

${ }^{6}$ This cause is not common in democratic states where public administration decision-making is subject to judicial review.
} 
- preventing public access to information that is legally accessible;

- arbitrary changes or loss of official documents;

- unusual dispersion in decision-making or individual decisions that are clearly contrary to the perceived public interest;

- infringement of rules which preclude the decision of an official body in a given case for its bias;

- above-standard frequent contacts of the Office's employees with the participants in the relevant proceedings;

- an official in a certain position so-called "lives beyond his means", he often ostentatiously shows his wealth.

\subsection{Occurrence of corruption in provision of public services and distribution of public goods by public administration and its indicators of corruption ${ }^{7}$}

Transparency International states in its document that "in case of provision of public services and distribution of public goods by public administration, corruption primarily seeks acquisition of certain limited public goods or services, such as municipal housing, prestigious university or high school places or preferential access to special medical care. A similar example could be, for example, gaining access to certain exclusive information from non-public databases maintained by public administration." (Transparency International, 2005b) Causes of corruptive practices in this area may be, for example, insufficient salary of decision-makers (or desire to enrich themselves or enrich their political "party treasury"). Furthermore, the emergence of corruption is made possible by missing or insufficiently set internal standards for the provision of these public services (goods) and missing or ineffective system for monitoring compliance with these standards. Finally, corruption in this area (as above) may be due to insufficient ethical standards for functioning of a competent authority (missing or ineffective code of ethics).

Indicators of corruption in the provision of public services can be considered:

- acquisition of a public service (public good) by a person who is clearly not entitled to it or who is entitled to it, but only after persons whose entitlement is stronger have been satisfied ("takes precedence");

- fact that person involved in the decision-making lives beyond his means;

- fact that a political party which has a decisive influence on the activities of collective bodies deciding on provision of public services (goods) is financed by a legal or natural person who has obtained the public service (goods);

- fact that entity which acquired public service or public good will subsequently employ a person who was involved in the decision or allocation of that service or good.

\subsection{Occurrence of corruption in the appearance of public administration as a private entity and its indicators 8}

In the case of public administration acting as a private entity, corruption is primarily aimed at obtaining a property benefit at expense of a state, ie a public administration body. This essentially property benefit may consist, for example, in excessive profits from acquisition of a particular public contract, or in excessive savings when a private entity purchases certain goods or services from a state. Reasons for this corrupt behavior in this area are again the above-mentioned insufficient salary evaluation of decision-makers (or the desire to enrich oneself or their political "party treasury"). Another cause may be a missing or ineffective public procurement methodology and missing or ineffective system for monitoring compliance with this methodology. Insufficient ethical standards for the functioning of the relevant authority, which is missing or ineffective code of ethics, may also be responsible for corruption in this area.

Indicators of corruption in the performance of public administration as a private entity can be considered:

- purchase and sale of goods and services by the public administration under conditions which are manifestly unfavorable to the public administration;

- fact that person involved in the decision-making lives beyond his means;

- fact that a political party which has a decisive influence on the activities of collective bodies deciding on public contracts is financed by the legal or natural person who won the contract;

- appointing representatives of public administration to executive or supervisory bodies of this legal entity;

- fact that a contracting entity will subsequently employ the person who was involved in award of the contract.

An important indicator of occurrence of corrupt practices, which is common to all above-mentioned activities of public administration, is secrecy of information, to which citizens have a legal right to provide it. Corrupt instruments in the area of public administration are, for example, monetary "donations", which also include share of profits from awarded public contracts, property "donations" or non-property counter-services (Chmelík, 2003).

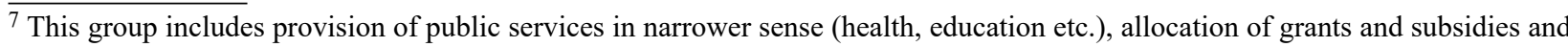
distribution of EU funds.

${ }^{8}$ This group includes, among other things, property management and public procurement.
} 


\section{Action plan for the fight against corruption in the Czech Republic}

Corruption is one of serious problems of Czech civil society. Fight against corruption at all levels of public administration is considered one of the government's priorities formulated in the Program Statement of the Government of the Czech Republic in 2014 and subsequently in the Action Plan against Corruption for 2021 and 2022. All forms of wasting public funds, transparent procurement, prevention of overuse of external services and consultants, disclosure of expenditure paid from taxpayers' money, including small-scale contracts, and the non-negotiable fight against all forms of corruption, including serious economic and financial crime. As for approach of the government of the Czech Republic, as stated in the cited documents, it refuses to go the way of long-term strategies, which are often difficult to implement, but tries to focus on simple and concise Action Plans to fight corruption for a selected short period, for example for 2 years. In the plans, the government then formulates and expands basic program documents of government coalition. These programs also seek to accept recommendations of international organizations and the European Commission in field of the fight against corruption, by which the Czech Republic is bound.

Legislative activity in the area of the government's fight against corruption is absolutely crucial. A necessary part of legislative process should be a thorough analysis of possible corruption risks in draft legal norms in order to prevent misinterpretation of the law and possible scope for corrupt practices. These are often lacking control mechanisms for decision-making processes that can effectively prevent this. Protection of whistleblowers is also being addressed by legislation.

The main area of the government's fight against corruption is public administration with an emphasis on state administration. The Czech Republic's international obligations have not yet been met, such as conflicts of interest, the general demand for depoliticisation of public administration, insufficient protection of whistleblowers, public procurement, greater transparency in the financing of political parties and more. ${ }^{9}$ A key point in the fight against corruption is also area of prevention, in particular training of civil servants and local government officials. It also includes transparency in broadest sense - smooth flow of open data and informing citizens about public sector spending. The Czech Republic is often considered a so-called signatory to many international treaties and a member of a number of international organizations. In some cases, area of corruption is mentioned only marginally, other international agreements concern mainly the fight against corruption - the Group of States against Corruption (GRECO), which is institutionally part of the Council of Europe. Internationally discussed issue is proving international corruption and its cross-border punishment. An important instrument governing the seizure and confiscation of proceeds of crime in the European Union is Directive 2014/42 / EU of the European Parliament and of the Council, which obliges Member States to take the necessary measures to allow total or partial confiscation of property by a sentenced person for his crime. ${ }^{10}$ Basic instrument for the fight against corruption in the Czech Republic for the following period is Action Plan for the Fight against Corruption for 2021 and 2022 (Ministry of the Interior Czech Republic, 2020). It sets out key legislative and non-legislative measures that the government will implement in the fight against corruption in year. The government's anti-corruption policy is based on four priorities.

The action plan is an anti-corruption document of the government. In addition to the assessment of corruption risks within the legislative process (preventive legislative institute enshrined in the Legislative Rules of the Government), the anti-corruption action plans are the main instrument for the fight against corruption at the governmental level. Their aim is to determine a set of specific anti-corruption measures that are recommendations from government program documents or international commitments of the Czech Republic or respond to the current social situation. Primary role in formulation of proposals for anti-corruption measures is going beyond the national or international obligations of the government, respectively of the Czech Republic, has a Government Council for the Coordination of the Fight against Corruption (hereinafter referred to as the "Council") composed of representatives of relevant actors in the field of the fight against corruption. In 2020, the majority of legislative proposals of anti-corruption nature, to which the government committed itself in the government's program documents, were submitted to legislative process, as well as implementation of majority of non-legislative measures. However, length of the legislative process in the Chamber of Deputies of the Parliament of the Czech Republic (hereinafter the "Chamber of Deputies") was negatively affected in 2020 by the Covid-19 pandemic, when a number of legislative proposals acutely responding to resolving the situation had to be given priority. For example, standards have not yet been approved to meet most of the recommendations of the Council of Europe Group of States against Corruption (GRECO), such as the amendment to the Law on Courts and Judges, the amendment to the Law on Proceedings in Judges, Prosecutors and Bailiffs, or proposal for lobbying regulation. It is also worth mentioning, among other things, discussion of the bill on the registration of beneficial owners and the amendment to the law on certain measures against money laundering and

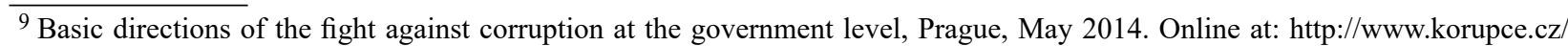
assets/dokumenty/aktuality/Zakladni-smery-boje-s-korupci-na-vladni-urovni.pdf [citation 2016-07-25] pages 3-5.

${ }^{10}$ Same as the citation above No. 8, pages 4-6.
} 
terrorist financing (transposition of the so-called V. AML Directive ${ }^{11}$ ) or the submission of a bill on whistleblower protection by the Parliament and the Council (EU) on the protection of persons reporting breaches of Union law to the government. For above-mentioned transposition proposals, as well as the draft transposition amendment to the Act on Free Access to Information, the Act on the Right to Environmental Information and the Act on Support for Research, Experimental Development and Innovation from Public Funds (Act on Support for Research, Experimental Development and Innovation), main purpose of which will be implemented by the Directive of the European Parliament and of the Council (EU) on open data and re-use of public sector information, it is necessary for the government to work within their competencies meant the threat of delaying or endangering the disbursement of part of the funds from the Recovery and Resilience Facility. The implementation of action plans to fight corruption is regularly subject of a separate detailed evaluation, which is submitted to the government in March of each year. This evaluation deals with the substance of individual tasks, ie to what extent intentions of the government and individual managers were fulfilled. In the second half of 2022, the Czech Republic will hold the Presidency of the Council of the EU in order to emphasize in the anti-corruption agenda two current topics, namely sharing experience in increasing protection of whistle-blowers through the implementation of the European Parliament and Council (EU) Directive on the protection of whistle-blowers. Also, the Czech Republic will be leading the discussion on the possibilities of ensuring a European minimum standard of lobbying regulation in individual EU member states. Thanks to legislative activities in these areas, the Czech Republic is interested in their proper implementation and unification of the European framework, including the evaluation of their practical impact on society.

\section{Examples of "good practice"}

In 2016, a questionnaire survey was conducted in the framework of the Workshop held on the occasion of creating new commitments to the Partnership for Open Governance initiative, which, among other things, called for development of a methodology for applying code of ethics in public administration. The questionnaire was attended by 120 respondents, 9 questionnaires were discarded due to insufficient data, 111 questionnaires were processed. In introduction, general questions were asked regarding the gender and age of respondents, in how large municipality respondents work and in what position. 13 respondents are officials of the capital city of Prague, 78 respondents are officials of the municipality with extended powers (from the district city) and 20 are from the municipality with an authorized municipal office. The professional representation of the respondents was diverse: 23 are from Department of Social and Legal Protection of Children, 17 are officials of the Department of Population Registration / Personal Documents, 12 are officials of the Department of Economics, they are responsible for budget or finance, 12 stated the position of clerk, 9 officials are from the Trade Licensing Office, 7 officials are deals with the recovery of local fees. 5 respondents forging activities in area of control and education and 4 in the area of crisis management and the Department of Transport, 13 respondents belong to group of others or did not specify the department where they perform state administration. Question 1 was whether a code of ethics was applied in the municipality concerned. 85 respondents answered yes, 16 respondents responded a citizen, 5 respondents responded rarely, 2 respondents stated outside the questionnaire that no code of ethics is applied in their department, and therefore they cannot answer whether it regulates behavior in order to prevent corruption. The respondents are working for a municipality with an authorized municipal office. One respondent stated that "it is a basic form of decency" and the other that it is necessary to behave "according to one's own consciousness and conscience." Question 2 was to find out whether the code of ethics regulates the conduct and actions of officials to prevent corruption. Three-quarters of respondents said that the code of ethics regulates very well or well enough behavior and actions of local government officials in order to prevent corruption. On the other hand, there are $20 \%$ of respondents who have no information about this fact at all. From the point of view of Secretary of Office, it would be appropriate to acquaint these officials with the function and meaning of the Code of Ethics, so that they will be able to assess its performance in practice in the performance of state administration. Further inquiries were aimed at transparency and open access to information. The aim of question no. 3 was to find out whether and how employees in public administration and self-government use the National Catalog of Open Data (NKOD), which is operated by the Ministry of the Interior on the Public Administration Portal. Only $11 \%$ of respondents answered that they use open public administration data for their work in the performance of state administration. Almost $70 \%$ of respondents answered in the negative and 19 respondents have no information that there is a National Catalog of Open Data. Questions 4, 5 and 6 concerned the area of economical management of state and municipal property. In question no. 4, the question was asked whether the expenditures of the TSU - territorial self-governing units (eg when dealing with the property of a municipality / city) are checked before the invoices are paid by a third party / independent person. One third of the respondents answered in the affirmative, 8 in the negative and 67 respondents answered that they did not have information about the given fact. Question no. 5 concerned the

\footnotetext{
${ }^{11}$ Directive 2018/843 of the European Parliament and of the Council of 30 May 2018 amending Directive 2015/849 on the prevention of the use of the financial system for the purpose of money laundering or terrorist financing and Directives 2009/138/ EC and 2013/36/EU.
} 
publication of the offer for the sale and lease of TSU assets on the TSU website and on the TSU official bulletin board. 100 respondents answered yes to that question, none expressed a negative opinion and only 7 respondents did not have information about the fact. Question no. 6 was aimed at whether the respondent is aware that the contracts for the sale and lease of the municipality / city are published on the website or on the official bulletin board of the TSU. 92 respondents stated that contracts are published regularly or occasionally and only 11 respondents were unaware of this obligation of the $\mathrm{CC}$. The last set of questions focused on the development of the occasional society and focused on corruption and corrupt practices. In question no. 7, the respondents were presented with 4 possibilities of corrupt conduct: acceptance of a bribe, acceptance of a gift, bribery, obstruction of an official's act. The options in the question were deliberately chosen so that they are all examples of corrupt practices and respondents should therefore tick all the options offered. 75 respondents chose only one option: 35 accepting a bribe, 31 bribing, 4 accepting a gift and 5 obstructing an official's act. 15 people chose two options and almost all chose to accept a bribe and bribery, 17 respondents ticked three options and added a gift to the two mentioned above (14) and only 3 people chose to obstruct the official's task. Only 4 respondents answered correctly, who chose all four offered options. In question 8 , they had to choose what is not considered corruption: acceptance of a bottle of alcohol, acceptance of a bouquet, provision of cash, provision of consideration. The respondents were very well acquainted with the fact that only the acceptance of a bouquet is not a corrupt act, 103 respondents answered correctly. The last question no. 9 offered the possibility of further education - lectures on the manifestations and consequences of corruption and corrupt practices. 51 respondents in the positive, 28 answered in the negative and 32 respondents did not know.

In the questionnaire survey carried out within the project Satisfaction of officials with the activities of public administration institutions ${ }^{12}$, not only officials of higher territorial self-governing units were addressed, but also clients of these officials themselves. Their answers were as follows. Respondents were asked to answer the question of whether they had encountered the official's corrupt practices. It is positive that only seven respondents confirmed these corrupt practices. In the ensuing question, they should have specified that action in more detail. The statements stated that they were small gifts, protectionism and money. It is not possible to determine here, but unequivocally, whether this question was filled in only by public administration clients or by officials themselves, who can also act as clients in their personal lives. However, this would be the subject of further investigation. The answers are shown in Figures 1 and 2 (Kamrádová et al., 2021).

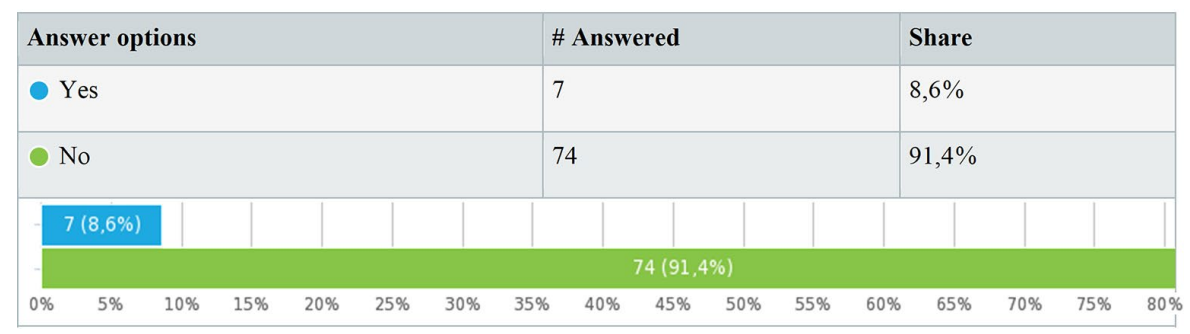

Figure 1. Presence of clients in corrupt actions of an official in public administration (source: own processing according to the questionnaire survey)

\begin{tabular}{|c|c|c|c|c|c|c|c|c|c|c|c|c|c|c|c|}
\hline \multicolumn{9}{|c|}{ Answer options } & \multicolumn{4}{|c|}{ \# Answered } & \multicolumn{3}{|c|}{ Share } \\
\hline \multicolumn{9}{|l|}{ Money } & \multicolumn{4}{|l|}{4} & \multicolumn{3}{|l|}{$40 \%$} \\
\hline \multicolumn{9}{|c|}{ Small gifts } & \multicolumn{4}{|l|}{5} & \multicolumn{3}{|l|}{$50 \%$} \\
\hline \multicolumn{9}{|c|}{ Protectionism } & \multicolumn{4}{|l|}{4} & \multicolumn{3}{|l|}{$40 \%$} \\
\hline \multicolumn{9}{|c|}{ Clientelism } & \multicolumn{4}{|l|}{2} & \multicolumn{3}{|l|}{$20 \%$} \\
\hline \multicolumn{9}{|c|}{ Another answer, please specify } & \multicolumn{4}{|l|}{0} & \multicolumn{3}{|l|}{$0 \%$} \\
\hline \multicolumn{16}{|c|}{$4(40 \%)$} \\
\hline \multicolumn{16}{|c|}{$5(50 \%)$} \\
\hline \multicolumn{16}{|c|}{$4(40 \%)$} \\
\hline \multicolumn{16}{|c|}{$2(20 \%)$} \\
\hline \multicolumn{16}{|l|}{$0 \%$} \\
\hline $0 \% \quad 5 \%$ & $10 \%$ & $15 \%$ & $20 \%$ & $25 \%$ & $30 \%$ & $35 \%$ & $40 \%$ & $45 \%$ & $50 \%$ & $55 \%$ & $60 \%$ & $65 \%$ & $70 \%$ & $75 \%$ & $80 \%$ \\
\hline
\end{tabular}

Figure 2. Specification of the subject of corruption (source: own processing according to the questionnaire survey)

$\overline{12}$ The questionnaire survey took place in 2019 in the Moravian-Silesian Region in the Czech Republic. 


\section{Conclusions}

The Czech Republic has been struggling with the issue of corruption and its definition since the very beginning of the modern democratic state (January 1, 1993), when it did not want to follow the opaque period of the communist regime. Various institutions and organizations call on society not to be indifferent to this phenomenon and, on the contrary, to spread enlightenment and protests (Ellenboren, 2010). The aim of the article was to point out the issue of corruption with regard to the application of an example from practice in the Czech Republic.

The issue of corruption is debatable at all levels of today's society. Unfortunately, the current global situation with the Covid-19 pandemic is undoubtedly an environment for the emergence of corrupt practices both in the political field (abuse of power and fear) and in the social field. This is evidenced by the spring "economic and financial struggles" of individual governments for protective equipment and private entities willing to provide such resources only to privileged groups or under artificially increased financial conditions. Despite the above, however, corruption has been linked to human society since its inception, thanks to the moral credit that is absent from this fact. In general, however, corruption has been tackled more actively since the 1990s, when political and social changes led governments and states to develop international and national standards for ethical and anti-corruption practices. In general, we can define these steps with the following statements:

- Corruption is always driven by the goal of gaining any advantage in any form.

- Individual states and organizations seek to eliminate this phenomenon through legislative documents, declarations and conventions.

- Corruption is considered a serious problem, especially in relation to public administration.

- There are several exhaustively defined areas that are affected by corruption in public administration.

- At the international and governmental level, however, there are indices and options for measuring the level of corruption at individual levels and in individual states.

- Officials themselves, but also the public, have a negative view of corruption, however, the level of the moral code cannot be influenced by an individual other than a good example.

It follows from the above and, among other things, from the article that the issue of corruption is very extensive and affects all spheres of civic and political life (it also concerns both executive, legislative and judicial powers). The very concept of corruption can be characterized from various perspectives. This may be an abuse of the position of an official in public administration, related to a violation of the principles of impartiality in decision-making or obtaining other benefits. It can also be, among other things, a failure of an official (individual), when he decides in performance of public administration. It can be targeted fraud. Unjust enrichment or gain of an advantage. However, it is always considered a secret act. The authors of the article tried to present the basic pillars of this issue, both in the theoretical level, which is represented by Chapters 1,2 and 3, and in the practical level, which is presented in Chapters 4 and 5. Throughout the article, the authors use the method of analysis and comparison. in the practical part they use quantitative methods of questioning supplemented by document analysis. These findings can serve as a basis for further research in this area, which would be interesting from the point of view of international comparison. According to the authors, the chance to spread awareness of this issue not only in the conditions of the Czech Republic is seen mainly within the framework of international projects based on the cooperation of universities. Examples are V4 projects or calls within the European Union. The empirical part of the article followed the theoretical basis of analysis of the issue of corruption in relation to legal documents and taxonomy of corruption as a social problem. In connection with the mentioned issues, the article focuses in the empirical part on examples of good practice in the Czech Republic with regard to corruption in public administration and participants - ie officials. Two sources of the research serve as sources in the given examples: 1) questionnaire survey among public administration officials in the Czech Republic within the project Satisfaction of officials with the activities of public administration institutions (ongoing in 2019-2020; 2) questionnaire survey within the Workshop held on the occasion of the creation of new commitments to the Open Governance Partnership initiative, which, called for the development of a methodology for application of the code of ethics in public administration (ongoing in 2016). These questionnaire surveys have shown that officials themselves have a negative view of corruption. Despite this fact, they meet it daily in their profession. This is also confirmed by current data from 2021, when Transparency International points to the fact that the Czech Republic fell again on the TI index by five places and found itself in 49th place. The above is not a positive fact and it is more than desirable, according to the authors, to draw attention to this issue not only in public administration but in all aspects of social life.

\section{Disclosure statement}

Authors declare no competing financial, professional, or personal interests from other parties. 


\section{References}

Chmelík, J. (2003). Attention, bribery and corruption. Linde.

Chmelík, J., \& Tomica, Z. (2011). Corruption and bribery. Linde.

Cohen, A.-G. (2007). Public internal financial control: A new framework for public sector management. The Institute of International Auditors, IIA Research Foundation.

Council of Europe. (1989). Convention on insider trading. ETS No. 130. https://www.coe.int/en/web/conventions/full-list/-/conventions/treaty/130

Council of Europe. (1999). Civil law convention on corruption. ETS No. 174. https://www.coe.int/en/web/conventions/full-list/-/conventions/treaty/174

Czech Press Office. (2021). Covid is also a corruption crisis. The Czechia lost five places on the corruption ranking. https://zpravy. aktualne.cz/domaci/cesko-si-mezi-zememi-na-zebricku-korupce-pohorsilo-o-pet-mis/r 2fe44a0c613311eb9d74ac1f6b220ee8/

Econnect. (2004). Monsanto was fined \$ 1.5 million for bribery. http://zpravodajstvi.ecn.cz/index.stm?apc=zzvx1-- \&x=218965

Ellenboren, M. S. (2010). Atlantic Eye: A Czech state of corruption. https://www.upi.com/Top_News/Special/2010/02/23/Atlantic-Eye-A-Czech-state-of-corruption/19771266959022/?ur3=1

European Parliament, \& Council of the European Union. (2014). Directive 2014/42/EU of the European Parliament and of the Council. https://eur-lex.europa.eu/legal-content/EN/TXT/?uri=CELEX\%3A32014L0042

European Parliament, \& Council of the European Union. (2018). Directive 2018/843 of the European Parliament and of the Council of 30 May 2018 amending Directive 2015/849 on the prevention of the use of the financial system for the purpose of money laundering or terrorist financing and Directives 2009/138/EC and 2013/36/EU. https:/eur-lex.europa.eu/legal-content/EN/ALL/?uri=CELEX\%3A32018L0843

Frič, P., Kabela, J., Rozehnal, A., Reed, Q., Žák, V., \& Burian, M. (1999). Corruption in the Czech way. G plus G.

Kamrádová, L., Kuděla, J., Sciskalová, M., \& Volkova, S. (2020). Selected problems of public administration. Silesian University in Opava.

Karklins, R. (2002). Typology of post-communist corruption. Problems of Post Communism, 49(4), $22-32$. https://doi.org/10.1080/10758216.2002.11655993

Králíček, V., \& Molín, J. (2014). External and internal control from the point of view of management. Wolters Kluwer.

Ministry of the Interior Czech Republic. (2005). Government Council for the Information Society. https://www.mvcr.cz/clanek/ rada-vlady-pro-informacni-spolecnost.aspx

Ministry of the Interior Czech Republic. (2008). Basic information on the Ministry of the Interior's progress in implementing the Government's strategy in the fight against corruption. https://www.mvcr.cz/webpm/clanek/zakladni-informace-o-postupuministerstva-vnitra-v-plneni-strategie-vlady-v-boji-proti-korupci.aspx

Ministry of the Interior Czech Republic. (2020). Action plan to fight corruption for 2021 and 2022. Internal documents.

OECD. (2004). Integrity and corruption prevention policies in the public service (Towards an assessment framework). Paris.

Rose-Ackerman, S. (1999). Corruption and government. Causes, consequences, and reform. Cambridge University Press. https://doi.org/10.1017/CBO9781139175098

Sawyer, L. (2000). Internal audit. Czech Institute of Internal Auditors.

Transparency International. (2000). Book of anti-corruption strategies. Transparency International - Czech Republic.

Transparency International. (2005a). Corruption and anti-corruption policy in public administration. Profile Books.

Transparency International. (2005b). Global corruption report 2005. Profile Books.

United Nations. (1996a). United Nations Declaration against Corruption and Bribery in International Commercial Transactions, G.A. res. 51/191, 51 U.N. GAOR Supp. (No. 49) at 176, U.N. Doc. A/51/49 (Vol. I) (1996). http://hrlibrary.umn.edu/resolutions/51/191GA1996.html

United Nations. (1996b). Action against corruption, G.A. res. 51/59, 51 U.N. GAOR Supp. (No. 49) at 182, U.N. Doc. A/51/49 (Vol. I) (1996). http://hrlibrary.umn.edu/resolutions/51/59GA1996.html 